\title{
A Study on Impact of Covid 19 on Selected Sectors of Indian Economy
}

\author{
Dr. Prashant T. Jariwala \\ Associate Professor, City C.U. Shah Commerce College, Opp. Dinbai Tower, Laldarwaja, \\ Ahmedabad, India.pjari66@gmail.com
}

\begin{abstract}
The COVID 19 pandemic is the first human catastrophe affecting a number of people all over the world. More than 175 countries have suffered due to cases of COVID 19, the diseases caused by the coronavirus (SARS-COV2). The economy of underdeveloped and developing countries are badly hit by this crisis. It directly effects on various sectors of the economy which have major contributors in GDP. India is one of the most emerging economies in the world. This paper attempts to focus the impact of COVID 19 on various sectors of Indian economy. Researcher is focusing to address key issues in selected sectors due to COVID 19. They also try to suggest ways in which sectors are likely to go forward in the coming days.
\end{abstract}

\section{KEYWORDS: COVID 19, Economy, Sectors, Impact}

\section{INTRODUCTION}

Coronavirus pandemic was first testified in Wuhan, China in Dec. 2019. It is the large family of virus that causes illness. This novel virus has not been recognized in humans so far. It has already been spread to more than 175 countries in the world. Global economy is badly hit by this COVID 19. The global economy is suffering the risk of global recession as most of the nations have declared lock down due to COVID 19. We cannot ignore that this crisis has a significant impact on economy includes trade, investment, commodities, logistics and supply chain. The global impact of China's slowdown is felt all over the world. It totally outbreaks disrupted the manufacturing supply chain and demand of commodities now it has spread to the service sector also. Due to steadily going into shutdown economic activity, clubbed with slow economic growth, especially in a developing country like India will lead to tremendously volatile market conditions. Coronavirus will impact our economic growth which will directly reflect in our GDP. According to Arun Singh, Chief Economist Dun \& Bradstreet this lockdown will decrease in GDP growth rate which is expected to moderate further from earlier estimate of 5\% for FY 20 and it will also be uncertain in FY 21. In this paper researcher has tried to find out the current and potential impact of coronavirus on selected sectors of the economy.

\section{OVERALL IMPACT ON INDIAN ECONOMY}

India is one of the fastest growing economies in the world. In 2017, as per data of World Bank, India stood on $6^{\text {th }}$ rank in largest economy with GDP of USD 2.59 trillion. Our country is now suffering due to this global crisis. This epidemic hit our economy which is seen in our third quarter
GDP growth rate for $2019-20^{1}$. As per recent data by NSO our economy raised at $4.7 \%$ during the third quarter. It is all time lowest in last six years.

Table 1.1 Quarterly GDP growth rate at 2011-12 prices (\%)

\begin{tabular}{|c|c|c|c|c|}
\hline YEARS & Q1 & Q2 & Q3 & Q4 \\
\hline $\mathbf{2 0 1 9 - 2 0}$ & 5.01 & 4.55 & NA & NA \\
\hline $\mathbf{2 0 1 8 - 1 9}$ & 7.95 & 7 & 6.58 & 5.83 \\
\hline $\mathbf{2 0 1 7 - 1 8}$ & 5.99 & 6.77 & 7.69 & 8.13 \\
\hline $\mathbf{2 0 1 6 - 1 7}$ & 9.37 & 8.87 & 7.55 & 7.04 \\
\hline $\mathbf{2 0 1 5 - 1 6}$ & 7.59 & 8.03 & 7.2 & 9.09 \\
\hline
\end{tabular}

Sources: - Ministry of statistic and programme implementation, 29 NOV 2019

Government has declared a 21 days lockdown to protect the people and also break the chain of this virus for spreading. Complete lockdown has brought most of the sectors (Except essential services. Public Administration and Defense) to a cessation. It also impacts our GDP growth rate. Private consumption, investment and external trade which are major contributors in GDP will have significant impact due to COVID 19. China has already controlled COVID 19. New cases are brought down but the coronavirus pandemic has now become black swan for other nations including India. If our economy will recover quickly by the mid of May, the growth rate may reach 5.3\%

\footnotetext{
${ }^{1}$ Ministry of statistic and programme implementation, $28^{\text {th }}$ February 2020, accessed on $25^{\text {th }}$ March 2020
} 
to $5.7 \%$. In case lock down will be extended the growth rate may fall below $5 \%$.

\section{OBJECTIVES}

- To study the impact of COVID 19 on selected sectors of economy.

- To provide suggestions and recommendations regarding COVID 19.

\section{METHODOLOGY}

It is a descriptive type of research and exploratory research design has been taken by researcher for doing this study. Secondary data have been collected for the research from various sources like newspapers, articles in journals, websites. To fulfil the objectives researcher has selected five sectors from industry and service, more ever researcher exclude agriculture sector which is main occupation in India. Majorly it depends on the season so the impact is uncertain. Selected sectors are,

\section{- Building and Construction}

- Auto

- Aviation and Tourism

- Pharma

- Oil \& Gas

\section{IMPACT ON SELECTED SECTORS}

\section{Building and Construction}

This sector is one the largest employment generator sectors in the economy, which is expected to contribute $13 \%$ to the GDP by 2025. Due to lockdown, construction work has totally shut down which may lead to losses on some projects. Due to the outbreak, the housing sector will need to wait for launching new schemes. In the first quarter of 2020(Jan.-Mar.) was much crucial for this sector as it accounts 30 to $40 \%$ of their annual revenue. Many companies have already suffered due to weak financial positions. The inflow of equity FDI would also slow down. Even after recovery in the last week of April, the upcoming monsoon will again obstruct their work. Materials like steel and iron ore which we import from China will also become costly. Work from home is not possible in this sector because the workers' physical presence is required. It will impact on employment.

\section{Auto}

The Auto sector contributes $7.1 \%$ in GDP and also provides approximately 40 million employment in our country ${ }^{2}$. The impact of COVID 19 would depend on the extent of their business with China. The shutdown in China has prohibited import of various components for the auto industry. Apart from China our supplier Germany and Japan are also

\footnotetext{
${ }^{2}$ Automobile and auto components sector overview, invest India website, accessed on $25^{\text {th }}$ March 2020
}

suffering due to this outbreak. Due to lock down production is totally shut down in the country. Normally China imports $25 \%$ of automotive parts but now it is expected in 8 to $10 \%$ contraction in Indian auto manufacturing in 2020. Customers have already postponed their purchase so this sector will also need to wait for any new launches for even some time. After lockdown customers will first prefer to purchase their necessity of goods like food, medicines they only spend for repair which will be necessary for maintenance. So, we can say that this crisis will have a long-term impact on the Auto sector.

\section{Aviation and Tourism}

The aviation sector has been most impacted by the spread of COVID 19. It has the very first sector which has been badly hit by coronavirus. The data of FY 18 shows that these contributed $2.4 \%$ and $9.2 \%$ in our GDP. Rajasthan, Kerala. Goa, Gujarat and Maharashtra are the key states to visit for foreigners. Last year 10.89 million foreigners visited India. Due to fear of COVID 19 and travel restriction, In Feb. 2020, 1.01 million foreign tourists arrived in India compared to 1.08 million in Feb. 2019. This shows the sharpest decreases since 2015 Due to COVID 19. Tour operators, travel agencies and branded hotels from organized sector may incur huge loss around Rs. 1.58 lakh crore according to Confederation of Indian Industry estimates. Apart from the organized sector, tourism also gives employment to small house stays and small dhaba and hotel operators will also take a major hit. The Indian tourism and hospitality industry is staring at a potential job loss of around 38 million which is around $70 \%$ of the total work force. International and domestic airlines have been closed. Prices of fuel will decline but large cancellation of tickets may incur huge loss for this sector. Job loss and salary cuts are likely in the high risk of aviation, tourism and hospitality it will lead the economy towards unemployment. We cannot ignore the truth that the market will come back to India in the next 12 to 18 months.

\section{Pharma}

The U.S. and Europe are our largest consumers for Pharma. These economies are expected to slow down with precautionary measures on trade which can have a flowing effect on domestic Pharma companies in India. The clang on the pharmaceutical industry is of major concern for India as our $69 \%$ of Active Pharmaceutical Ingredients (API) are imported from China (As per CRISIL Report). These ingredients are essential to a large number in Pharma companies. Since pandemic started in China, supply from their ingredients has much reduced. Our companies have already created buffer stock for $2-3$ months so for a short time of period say 23 months there will be no much tension due to adequate stock. Once Chinese companies' restart production, APIs will be resolved. If this outbreak will be extended in China then we will have to pay higher costs for required ingredients for generics production. We can say 
that there is a mixed gain and loss impact of COVID 19 on Pharma.

\section{Oil \& Gas}

The overall demand of petrol, diesel and aviation turbines has fallen down which will reduce consumption from the oil \& Gas industry. The crude oil price correction has a mixed impact on Indian refiners. Crude oil prices have fallen almost $20 \%$ to $\$ 55.14$ per barrel in a month as China is one of the largest consumers. Oil sellers have been looking forward to alternative buyers in Asia for cargo deliveries as demand from China fell down. India has been one of the beneficiaries of the COVID 19 outbreak in China. Our refiner BPCL has purchased shipwrecked consignment form Mediterranean regions at discount rate. On other hand India exports approximately 34\% of petrochemicals output to China. Exports to China were hit due to the outbreak, so our refiners also found new markets immediately. Petrochemical prices will be further down stress due to COVID 19. In case of plastic it will have a positive impact as India imports most of cheap plastic materials from China. Due to COVID 19 our domestic plastic manufacture will have gained in a long time. Our domestic fuel prices depend on global oil prices so the fall in global oil prices will lead to some inventory losses for Indian oil refiners. According to Moody's weak oil prices will reduce the profitability of oil and gas companies.

\section{FINDINGS AND CONCLUSIONS}

From the above study researcher has concluded that from the selected sectors Pharma, Auto and Aviation have been impacted most by the outbreak of corona virus. According to research pharma and auto sector may also face the challenges in supply chain if the lock down extends. It may lead price rise up to $10 \%$.

WHO already declared COVID 19 outbreak as pandemic so panic riveted the financial market of all over the world including India. Many brokerage firms and Credit rating agencies recently have undertaken the research for knowing the impact of COVID 19 on the economy. Researcher has made an attempt to analyze how this slowdown will impact selected sectors of Indian economy. Following are the major findings concerning the objectives framed by researcher. COVID 19 has disturbed our supply chain management and it can clearly be seen form the following findings.

- The pandemic has a major impact on the Auto and Construction sector as India imports automobile components and tires from China. Construction and Real estate also suffer due to materials. It may create price volatility in materials. In the short term these inventories are adequate but for a long term it may cause losses for these sectors.
- Falling oil prices have a positive for Indian economy and there is a mixed impact of this outbreak on Pharma.

- Consumption goes down in the present scenario for many products like Auto, Real Estate, oil \& petrochemicals, it directly affects the production. It may create a huge risk for the workforce.

- Our economy is going through a major slowdown and resulted in the third quarter GDP growth rate of $4.7 \%$ which is the lowest in six years.

- Tourism, Aviation and hospitality sectors are the most affected sectors. Closing of domestic and international airlines, restaurants, shopping complexes and allied sectors are facing maximum impact.

- Some sectors may take tough decisions such as cutting down salary or other cost cutting measures for sustainment in this environment because their economic activities are totally shut down.

- For some sectors, work from home is a challenging task and is not possible for daily wages workers.

- On the other hand we can say that India can have benefits in the medium term because companies try to rely less on China as their materials, additional parts, ingredients will motivate domestic producers and we expect that to relatively increase GDP in upcoming years.

\section{RECOMMENDATIONS}

Govt. should take some strong financial stimulus for the middle and poor class of people so they will enable to purchase things which will help to sectors of economy to manage consumer demand.

Experts, industry members have also given their suggestion to recover the economy from this crisis. Our finance minister has already announced the relief packages and RBI has taken steps and allayed the immediate concerns of the Indian sectors. Union Ministry of Tourism already told that the govt. will help the sectors by giving soft loans, working capital and deferment on loan repayment. Apart from that there is a need to take some steps for minimizing the impact of this outbreak.

- To maintain working capital level by providing short to medium term loan s by banks and financial institutions'

- To Increase the credit limits for regular bank accounts for overdraft and Commercial credit.

- To give incentives to the employers so they can keep their workers after recovery.

- To give capital assistance for small and medium scales industries.

- Income tax reduction on loan for attracting the customers especially in Auto sector. 
- To stay of GST payment for some period to remove liquidity crisis.

- $\quad$ Some special relief in excise taxes, in electricity in Tourism sector and treat them as a priority sector lending.

- To give relaxation for project delays in Real estate

- The need to reduce dependence on china for APIs and crate partnership with European countries and U.S for better opportunities to export our pharmaceutical products for long time.

\section{REFERENCES}

[1] (2020). Retrieved from https://home.kpmg/content/dam/kpmg/in/pdf/2020 /04/potential-impact-of-covid-19-on-the-Indianeconomy.pdf.

[2] (2020). Retrieved from https://www.jagranjosh.com/generalknowledge/what-is-the-impact-of-coronavirus-onindian-economy-1582870052-1.

[3] (2020). Retrieved from adb.org/publications/series/adbbriefs.

[4] (2020). Retrieved from economics.rabobank.com/publications/2020/march /coronovirus/economic/impact/covid/19/on/India.

[5] (2020). Retrieved from http://www.ficci.in/publication.asp?spid=23195.

[6] (2020). Retrieved from https://bfsi.eletsonline.com/covid-19-and-itsimpact-on-indian-economy/.

[7] (2020). Retrieved from https://economictimes.indiatimes.com/news/econo my/indicators/covid-19-impact-how-to-shield-theeconomy/articleshow/74682449.cms?from=mdr.

[8] (2020). Retrieved from https://home.kpmg/in/en/home/insights/2020/04/na vigating-the-covid-19-crisis.html.

[9] (2020). Retrieved from https://www.businesstoday.in/opinion/columns/cor onavirus-in-india-covid-19-india-lockdowneconomy-cost-gdp-gva-nationwideshutdown/story/399477.html.

[10] (2020). Retrieved from https://www.thehindubusinessline.com/economy/c ovid-19-impact-adb-expects-indias-economicgrowth-to-slow-down-to-4-per-cent-infy21/article31243955.ece. 